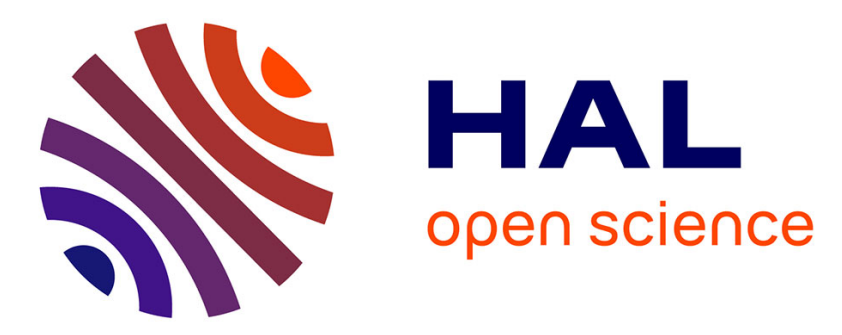

\title{
Detection of irrigation events on maize plots using Sentinel-1 soil moisture products
}

Michel Le Page, Lionel Jarlan, Aaron Anthony Boone, Mohammad El Hajj, Nicolas Baghdadi, Mehrez Zribi

\section{- To cite this version:}

Michel Le Page, Lionel Jarlan, Aaron Anthony Boone, Mohammad El Hajj, Nicolas Baghdadi, et al.. Detection of irrigation events on maize plots using Sentinel-1 soil moisture products. EGU General Assenbly 2020, May 2020, Vienna, Austria. hal-02881882

\section{HAL Id: hal-02881882 \\ https://hal.inrae.fr/hal-02881882}

Submitted on 26 Jun 2020

HAL is a multi-disciplinary open access archive for the deposit and dissemination of scientific research documents, whether they are published or not. The documents may come from teaching and research institutions in France or abroad, or from public or private research centers.
L'archive ouverte pluridisciplinaire HAL, est destinée au dépôt et à la diffusion de documents scientifiques de niveau recherche, publiés ou non, émanant des établissements d'enseignement et de recherche français ou étrangers, des laboratoires publics ou privés. 
EGU2020-8588

EGU General Assembly 2020

(c) Author(s) 2020. This work is distributed under

the Creative Commons Attribution 4.0 License.

\title{
Detection of irrigation events on maize plots using sentinel-1 soil moisture products
}

\author{
Michel Le Page ${ }^{1}$, Lionel Jarlan ${ }^{1}$, Aaron Boone ${ }^{2}$, Mohammad El Hajj ${ }^{3}$, Nicolas Baghdadi ${ }^{3}$, and \\ Mehrez Zribi ${ }^{1}$ \\ ${ }^{1}$ CESBIO (UPS/CNRS/IRD/CNES/INRA), 18, Avenue Edouard Belin, 31401, Toulouse Cedex 9, France \\ ${ }^{2}$ CNRM (Météo-France/CNRS), Toulouse, France \\ ${ }^{3}$ INRAE, UMR TETIS, University of Montpellier, 34093 Montpellier Cedex 5, France
}

An accurate knowledge of irrigation timing and rate is essential to compute the water balance of irrigated plots. However, at the plot scale irrigation is a data essentially known by the irrigator. These data do not go up to higher management scales, thus limiting both the management of water resources on a regional scale and the development of irrigation decision support tools at the farm scale. The study focuses on 6 experimental plots in the south-west of France. The new method consists in assessing surface soil moisture (SSM) change between observations and a water balance model. The approach was tested using both in situ measurements and surface soil moisture (SSM) maps derived from Sentinel-1 radar data. The score is obtained by assessing if the irrigation event is detected within +/- three days. The use of in situ SSM showed that: (1) the best revisit time between two SSM observations is 3 days; short gaps is subject to uncertainties while longer gap miss possible SSM variations; (2) in general, higher rates (>20 $\mathrm{mm}$ ) of irrigation are well identified while it is very difficult to identify irrigation event when it is raining or when irrigation rates are small $(<10 \mathrm{~mm})$. When using the SSM microwave product, the performances are degraded but are still acceptable given the discontinuity of irrigation events: $34 \%$ of absolute error and a bias of $5 \%$ for the whole season. Although high vegetation cover degrades the SSM absolute estimates, the dynamic appeared to be in accordance with in-situ measurements. 